\title{
ANALISIS PERBANDINGAN KINERJA KEUANGAN BANK PEMERINTAH DAN BANK SWASTA DI BURSA EFEK INDONESIA (BEI) PERIODE 2008 - 2012
}

\author{
Vivi Putri Maharani \& Chairil Afandy \\ Program Studi Manajemen Fakultas Ekonomi Universitas Bengkulu
}

\begin{abstract}
The purpose of this research was to determine whether there are significant differences in the (LDR, NPL, ROA, ROE, ROA, NIM and PDN) between government bank compared to private banks in Indonesia Stock Exchange (IDX) the period of 20082012. Method of sample selection was done by purposive sampling, the samples obtained from government banks such as BNI, BRI, BTN, and Mandiri bank, while from private banks such as BCA, BII, CIMB Niaga Bank and Panin Bank. Data analysis methods is hypothesis testing using two different test mean (pair sample $t$ test). The results showed that the financial performance of the ratio for LDR, NPL, ROA, ROE, ROA and PDN there is no significant difference between the government banks and private banks. While the financial performance of the NIM ratio there are significant differences between the government banks and private banks.
\end{abstract}

Keywords: Loan to Deposit Ratio, Non Performing Loan, ReturnOn Asset, Return On Equity, Biaya Operasional terhadap pendapatan operasional, Net Interest Margin dan Posisi Devisa Netto.

\section{PENDAHULUAN}

\section{Latar Belakang}

Lembaga perbankanmerupakan salah satu lembaga keuangan yang mempunyai nilai strategis dalam kehidupan perekonomian suatu Negara. Lembaga tersebut dimaksudkan sebagai perantara pihak-pihak yang mempunyai kelebihan dana (surplus offunds), dengan pihak-pihak yang memerlukan dana (lack of funds). Dengan demikian perbankan akan bergerak dalam kegiatan perkreditan dan berbagai jasa yang diberikan, serta bank juga melayani kebutuhan pembiayaan, melancarkan mekanisme sistem pembayaran bagi semua sektor perekonomian dan peredaran uang.

Dalam Undang-Undang Perbankan No.10 Tahun 1998jugatelah ditegaskan bahwa Bank Indonesia mempunyai wewenang untuk mengadakan penilaian terhadap kinerja suatu bank dapat dilakukan dengan cara melakukan analisis terhadap laporan keuangannya. Pengukuran suatu bank dapat diukur melalui rasiorasio keuangan. Rasio keuangan dapat digunakan sebagai dasar pembuatan keputusan, serta untuk membandingkan kinerja perusahaan satu dengan yang lain.

Kementerian BUMN mengklaim kinerja bank-bank BUMN lebih bagus dibanding bank-bank swasta meskipun dalam kondisi krisis. Kinerja keuangan Bank BUMN lebih bagus tercermin dari rasio keuangan yang lebih positif dibanding swasta. Pemberian kredit yang selektif dan menekankan prinsip kehati-hatian (prudent), mengakibatkan rasio kredit bermasalah (NPL) dapat ditekan, bahkan 
lebih rendah dibanding bank-bank swasta. pertumbuhan kredit bank pemerintah ini juga setara dengan yang ditargetkan BI (Bank Indonesia) sebesar 20 persen. (Antara News)

Dilihat dari data kinerja keuangan bank yang sering digunakan dan datanya pun lengkap dikeluarkan secara berturut-turut peneliti mengunakan tujuh indikator dari metode CAMELS antara lain yaitu dari aspek likuiditas dapat diketahui berapa tingkatl ikuiditas yang diperoleh bank untuk memenuhi kewajibannya peneliti menggunakan indikator Loanto Deposit Ratio(LDR). Dari aspek kualitas aktiva produktif dapat diketahui kinerja dalam menangani aktiva produktif yang bermasalah peneliti menggunakan indikator Non Performing Loan (NPL). Dari aspek rentabilitas dapat diketahui berapa tingkat keuntungan yang dihasilkan dan tingkat efisiensi yang dihasilkan indikator yang digunakan oleh peneliti yaitu semuanya antar lain Return On Asset (ROA), Return On Equity (ROE), Beban Operasional \& Pendapatan Operasional (BOPO) dan NettInterest Margin (NIM). Sedangkan dari rasio sensitivitas terhadap risiko pasar dapat diketahui pergerakan harga pasar yang merugikan bank, baik itu suku bunga maupun valas peneliti menggunakan Posisi DefisaNetto(PDN).

Berdasarkan uraian yang telah dijelaskan diatas, maka tujuan yang ingin dicapai dalam penelitian ini adalah mengetahui signifikansi perbedaan pada LDR, NPL, ROA, ROE, BOPO, NIM dan PDNantara bank pemerintah dibandingkan dengan bank swasta di Bursa Efek Indonesia (BEI).

\section{TINJAUAN PUSTAKA}

\section{Pengertian Bank, Bank Pemerintah dan Bank Swasta}

Menurut surat keputusan Menteri Keuangan RI Nomor 792 tahun1990 dan Standar Akuntansi Keuangan (SAK) pengertian Bank adalah bank merupakan suatu badan yang kegiatannya dibidang keuangan melakukan penghimpunan dan penyaluran dana kepada masyarakat terutama guna membiayai investasi perusahaan. Sedangkan menurut Stuart dalam Muhtar (2010), Bank adalah badan usaha yang wujudnya memuaskan keperluan orang lain, dengan memberikan kredit berupa uang yang diterimanya dari orang lain (nasabah).Berdasarkan definisidefinisi diatas maka dapat disimpulkan bahwa bank adalah lembaga keuangan yang kegiatannya menghimpun dan menyalurkan dana dari masyarakat untuk masyarakat yang berfungsi untuk memperlancar lalulintas pembayaran.

Menurut Cahyudi dalam Gustin (2007), Bank pemerintah adalah bank yang akta pendirian maupun sahamnya dimiliki pemerintah, sehingga seluruh keuntungannya dimiliki oleh pemerintah. Sedangkan bank swasta adalah bank yang seluruh atau sebagian kepemilikannya dimiliki oleh pihak swasta. Baik bank swasta maupun bank pemerintah bersaing untuk dalam mencapai tujuan bisnisnya. Bank pemerintah memiliki keuntungan karena kepemilikan oleh pemerintah sehingga dipersepsikan oleh masyarakat sebagai bank yang permodalan dan kinerjanya akan selalu disokong oleh pemerintah. Oleh karena itu masyarakat lebih memilih menabungkan uangnya di bank pemerintah dari pada bank swasta karena dipandang lebih aman. 


\section{Fungsi Bank}

Fungsi bank dalam Undang-undang perbankan pasal 3 adalah "fungsi utama dalam perbankan Indonesia adalah sebagai penghimpun dan penyalur dana masyarakat". Dari pasal tersebut dapat disimpulkan bahwa fungsi bank dalam sistem perbankan Indonesia sebagai intermediary bagi masyarakat yang surplus dana dan masyarakat yang kekurangan dana.

Kegiatan-kegiatan yang dijalankan oleh bank pada dasarnya ditentukan antara lain oleh fungsi-fungsi yang melekat pada bank yang bersangkutan. Menurut Sutami (2011) fungsi bank adalah :

1. Fungsi Pengumpul Dana, melalui pengumpulan uang masyarakat dalam bentuk tabungan, giro, dan defosito. Ketiga sumber dana tersebut merupakan sumber modal bank selain sumber modal yang berasal dari modal bank, yang terdiri dari modal penyertaan dan laba yang tidak dibagikan.

2. Fungsi Pemberian Kredit, yang merupakan salah satu bentuk usaha bank. Usaha ini dianggap paling menguntungkan pihak bank dan tidak banyak menganggu likuiditas bank karena biasanya berupa kredit jangka pendek.

3. Fungsi Penanaman Dana atau Investasi, dalam bentuk surat berharga, baik surat tanda kepemilikan (saham) atau surat tanda utang (obligasi, surat wesel).

4. Fungsi Pembayaran, melalui pencairan cek, bilyer giro, surat wesel, transfer uang dan sebagainya.

5. Fungsi pemindahan uang, yakni kegiatan uang, yakni kegiatan transfer yang dari suatu bank ke bank lainnya.

\section{Kinerja Keuangan Bank dengan Mengunakan Metode CAMELS}

Kinerja keuangan perbankan adalah gambaran kondisi keuangan bank pada suatu periode tertentu menyangkut berbagai aspek diantaranya aspek penghimpunan dana, kecukupan modal, likuiditas, dan profitabilitas. Kinerja keuangan perbankan juga merupakan salah satu faktor penting yang dapat menunjukkan efektifitas dan efisiensi perbankan dalam mencapai tujuannya. Indikator-indikator keuangan juga dapat dipakai sebagai system peringatan terhadap kemunduran kondisi keuangan suatu perusahaan.

Salah satu ukuran yang dapat digunakan menilai kinerja keuangan perbankan adalah nilai CAMELS (Capital, Assets, Management, Earning, Liquidity and Sensitivity to market). CAMELS juga dapat mengukur apakah manajemen bank telah melaksanakan sistem perbankan dengan baik. Rasio-rasio dalam CAMELS bisa menjadi alat prediksi kemungkinan kegagalan dari perbankan untuk jangka waktu satu sampai lima tahun sebelum bank tersebut benar-benar bangkrut (Aryati, 2002).

\section{Analisis Laporan Keuangan Bank}

Menurut (Dahlan Siamat, 2005) jenis-jenis laporan keuangan bank yang pada umumnya digunakan ada enam,laporan-laporan tersebut antara lain:

1. Neraca

Neraca merupakan laporan yang menunjukkan posisi keuangan bank . Posisi keuangan yang dimaksudkan adalah posisi Aktiva(Harta), Passiva (Kewajibandan Ekuitas) suatu bank yang disusun berdasarkan tingkat kelancarannya sesuai dengan standar akuntansi secara umum.

2. Laporan Laba-Rugi

Laporan laba-rugi merupakan laporan keuangan bank yang menggambarkan 
hasil usaha bank dalam suatu periode tertentu. Perhitungan laba rugi dan saldo laba bank pada dasarnya disusun dengan mengelompokkan pendapatan danbeban atau biaya ke dalam pendapatan dan beban operasional dan pendapatan dan beban non operasional. Pengelompokkan tersebut dilakukan untuk lebih mempermudah perhitungan masing-masing komponen pendapatan dan beban baik yang operasional maupun yang non operasional.

3. Laporan Komitmen dan Kontinjensi

Laporan komitmen merupakan suatu ikatan atau kontrak yang berupa janji yang tidak dapat dibatalkan secara sepihak (Irrevocable) dan harus dilaksanakan apabila persyaratan yang telah disepakati bersama dipenuhi. Contoh laporan komitmen adalah komitmen kredit, komitmen penjualan atau pembelian aktiva bank dengan syarat Repurchase Agreement (Repo), sedangkan laporan kontijensi merupakan tagihan atau kewajiban bank yang kemungkinan timbulnya tergantung pada terjadi atau tidaknya satu atau lebih peristiwa dimasa yang akan datang. Penyajian laporan komitmen dan kontijensi disajikan tersendiri tanpa pos lama.

4. Laporan Arus Kas

Laporan arus kas merupakan laporan yang menunjukkan semua aspek yang berkaitan dengan kegiatan bank baik yang berpengaruh langsung atau tidak langsung terhadapkas. Laporan arus kas harus disusun berdasarkan konsep kas selama periode laporan.

5. Catatan atas laporan keuangan

Catatan atas laporan keuangan merupakan laporan yang berisi catatan mengenai posisi devisa netto menurut jenis mata uangdan aktivitas lainnya.

6. Laporan Keuangan Gabungan dan Konsolidasi

Laporan keuangan gabungan merupakan laporan gabungan dari seluruh cabang yang bersangkutan baik yang ada di dalam negeri dan di luar negeri. Sedangkan laporan konsolidasi merupakan laporan bank yang bersangkutan dengan anak perusahaannya.

Variabel Loanto Deposit Ratio (LDR), Non Performing Loan (NPL), Return OnAsset (ROA), Return On Equity (ROE), Biaya Operasional terhadap pendapatan operasional (BOPO), Net Interest Margin (NIM), Posisi Devisa Netto (PDN)

1. Loan to Deposit Ratio (LDR)

LDR merupakan rasio yang mengukur kemampuan bank untuk memenuhi kewajiban keuangan yang harus segera dipenuhi. Kewajiban tersebut berupa call money yang harus dipenuhi pada saat adanya kewajiban kliring, dimana pemenuhannya dilakukan dari aktiva lancar yang dimiliki perusahaan (Sudarini, 2005). Sebagaimana rasio likuiditas yang digunakan dalam perusahaan secara umum juga berlaku bagi perbankan. Namun perbedaannya dalam likuiditas perbankan tidak diukur dari acid test ratio maupun current ratio, tetapi terdapat ukuran khusus yang berlaku untuk menentukan likuiditas bank sesuai dengan peraturan Bank Indonesia.

Rasio likuiditas yang lazim digunakan dalam dunia perbankan terutama diukur dari Loan to Deposit Ratio(LDR). Besarnya LDR mengikuti perkembangan kondisi ekonomi Indonesia, dan sejak akhir tahun 2001 bank dianggap sehat apabila besarnya LDR antara $80 \%$ sampai dengan $110 \%$. 


$$
L D R=\frac{\text { Kredit yang diberikan }}{\text { Total dana pihak ketiga }} \times 100
$$

\section{Non Performing Loan (NPL)}

Menunjukkan kualitas aktiva kredit yang jika kolektibilitasnya kurang lancar, diragukan dan macet dari kredit secara keseluruhan, maka bank tersebut mengalami kredit bermasalah. NPL yang naik menunjukkan adanya lonjakan outstanding pinjaman suatu bank. Semakin tinggi nilai rasio ini maka semakin jelek kualitas kredit bank yangbersangkutan karena jumlah kredit bermasalah semakin besar.Hal ini juga berdampak pada pendapatan dan labayang akan cenderung menurun. Besarnya nilai Non Performing Loan (NPL) suatu bank dapat dihitung dengan rumus sebagai berikut :

$$
N P L=\frac{\text { Kredit bermasalah }}{\text { Total kredit }} X 100
$$

3. Return on Assets (ROA)

Menjaga tingkat profitabilitas merupakan hal yang penting bagi bank karena (profitabilitas) yang tinggi merupakan tujuan setiap bank. Jika dilihat dari perkembangan rasio profitabilitas menunjukkan suatu peningkatan hal tersebut menunjukkan kinerja bank efisien. (Meythi, 2005). Analisis rasio profitabilitas ini menggunakan ROA alasan penggunaan ROA dikarenakan BI sebagai Pembina dan pengawas perbankan yang lebih mementingkan aset yang dananya berasal dari masyarakat (Meythi, 2005).

Return On Assets (ROA) yaitu Rasio ini digunakan untuk mengukur kemampuan manajemen bank dalam memperoleh keuntungan (laba sebelum pajak) yang dihasilkan dari rata-rata total aset bank yang bersangkutan. Semakin besar ROA, semakin besar pula tingkat keuntungan yang dicapai bank sehingga kemungkinan suatu bank dalam kondisi bermasalah semakin kecil. Laba sebelum pajak adalah laba bersih dari kegiatan operasional sebelum pajak. Sedangkan rata-rata total aset adalah rata-rata volume usaha atau aktiva. Rasio ini dirumuskan sebagai berikut :

$$
R O A=\frac{\text { Laba sebelum pajak }}{\text { Rata }- \text { rata total asset }} X 100
$$

4. Return on Equity (ROE)

ROE menunjukan perbanding anantara lababersih bank dengan modal sendiri. Rasio ini digunakan untuk mengukur kemampuan manajemen bank dalam mengelola modal yang adauntuk memperoleh laba bersih dari kegiatan operasional. Rasioini dapat dihitung menggunakan rumus:

$$
R O E=\frac{\text { Laba setelah pajak }}{\text { modal sendiri }} \times 100
$$

5. Biaya Operasional terhadap pendapatan operasional (BOPO)

Rasio ini digunakan untuk perbandingan antara biaya operasional dengan pendapatan operasional. Rasio ini digunakan untuk mengukur tingkat efisiensi 
dan kemampuan bank dalam melakukan kegiatan operasionalnya. Biaya operasional yang dimaksud adalah semua biaya yang berhubungan langsung dengan kegiatan usaha bank. Sedangkan pendapatan operasional adalah semua pendapatan yang merupakan hasil langsung dari kegiatan usaha bank yang merupakan pendapatan yang diterimabank. Rasioini dapat dihitung menggunakan rumus:

$$
B O P O=\frac{\text { Biaya operasional }}{\text { pendapatan operasional }} \times 100
$$

6. $\quad$ Net Interest Margin (NIM)

Rasio ini digunakan untuk mengukur kemampuan manajemen bank dalam mengelola aktiva produktifnya untuk menghasilkan pendapatan bunga dari kegiatan operasional bank. Kenaikan dalam rasioini berarti terjadi kenaikan laba bersih dari bank yang bersangkutan. Untuk perhitungan pendapatan bersih diperoleh dari selisih antara pendapatan bunga dan beban bunga, sedangkan untuk aktiva produktif yang diperhitungkan adalah aktiva produktif yang mengasilkan bunga. Rasioini dapat dihitung menggunakan rumus:

$$
\text { NIM }=\frac{\text { Pendapatan bunga }- \text { Beban bunga }}{\text { rata }- \text { rata aktiva produktif }} X 100
$$

7. Posisi Devisa Netto (PDN)

Rasio ini yang digunakan agar bank selalu menjaga keseimbangan posisi antara sumber dana valas dan penggunaan dana valas. Sesuai denganPeraturan Bank IndonesiaNomor5/13/PBI/2003tentang Posisi Devisa Netto bank umum. Rasio ini merupakanperbandingan antara selisih bersih aktivadanpasivavalas ditambah selisih bersih tagihan dan kewajiban baik yang merupakan komitmen maupun kontijensi dalam rekening administratif untuk setiap valuta asing dengan modal, yang semuanya dinyatakan dalam rupiah. Rasio ini dirumuskan sebagai berikut :

$$
P D N=\frac{(\text { Aktiva palas+of balance sheet)-(pasiva palastofbalance sheet) }}{\text { Modal }} \times 100
$$

\section{METODELOGI PENELITIAN}

\section{Jenis Penelitian}

Jenis penelitian yang akan digunakan dapat ditinjau dari beberapa aspek, di antaranya:

1. Ditinjau dari tujuannya, penelitian ini termasuk jenis penelitian komparatif, karena bertujuan mengetahui perbedaan antara kinerja keuangan bank pemerintah dengan bank swasta.

2. Ditinjau dari jenis datanya, penelitian ini termasuk penelitian kuantitatif, yaitu data penelitian yang dinyatakan dalam bentuk angka yang dilihat dari laporan keuangan periode 2008-2012 padabank-bank yang akan diteliti. 


\section{Definisi Operasional}

Berdasarkan identifikasi variabel, maka variabel-variabel tersebut dapat didefinisikan sebagai berikut:

1. Loanto Deposit Ratio (LDR) adalah perbandingan atau hasil pembagi anantara kredit dengan dana pihak ketiga dari bank pemerintah dan bank swasta pada setiap tahun mulai dari tahun 2008 sampai dengan tahun 2012. Satuan pengukuran rasio inia dalah prosentase (\%).

2. Non Performing Loan (NPL) adalah hasil perbandingan antara kredit bermasalah dengan total kredit berdasarkan laporan keuangan bank pemerintah dan bank swasta pada setiap tahun mulai dari tahun 2008 sampai dengan tahun 2012. Satuan pengukuran rasio ini adalah prosentase (\%).

3. Return On Asset (ROA)adalah hasil perbandingan laba sebelum pajak dengan rata-rata total asset. Pengukuran ROA untuk bank pemerintah dan bank swasta pada setiap tahun mulai dari tahun 2008 sampai dengan tahun 2012. Satuan pengukuran rasio inia dalah prosentase (\%).

4. Returnon Equity (ROE) adalah hasil perbandingan antara laba bersih bank dengan modal sendiri. Pengukuran ROE untuk bank pemerintah dan bank swasta pada setiap tahun mulai dari tahun 2008 sampai dengan tahun 2012. Satuan pengukuran rasio ini adalah prosentase (\%).

5. Biaya Operasional terhadap pendapatan operasional (BOPO)adalah hasil perbandingan antara biaya operasional dengan pendapatan operasional. Pengukuran BOPO untuk bank pemerintah dan bank swasta pada setiap tahun mulaidari tahun 2008 sampai dengan tahun2012. Satuan pengukuran rasio ini adalah prosentase (\%).

6. Net Interest Margin (NIM) adalah hasil pengukuran kemampuan manajemen bank dalam mengelola aktiva produktifnya untuk menghasilkan pendapatan bunga dari kegiatan operasional bank dari bank pemerintah dan bank swasta pada setiap tahun mulai dari tahun 2008 sampai dengan tahun 2012. Satuan pengukuran rasio ini adalah prosentase (\%).

7. Posisi Devisa Netto ( P D N) adalah hasil penjumlahan nilai absolut atas jumlah dari selisih bersih aktiva valas dan pasiva valas ditambah dengan selisih bersih tagihan dan kewajiban rekening administrative valas, baik menyangkut komitmen maupun kontijensi yang dimiliki bank pemerintah dan bank swasta pada setiap tahun mulai dari tahun 2008 sampai dengan tahun2012. Satuan pengukuran rasio ini adalah prosentase (\%).

\section{Metode Pengumpulan Data}

Data yang digunakan dalam penelitian ini merupakan data sekunder. Metode pengumpulan data yang digunakan adalah metode dokumentasi, yaitu mengumpulkan data atau dokumen dari laporan keuangan bank pemerintah dan bank swasta di BEI, website, serta buku rujukan atau laporan keuangan bank lainnya. Serta data sekunder lain yang diperoleh secara tidak langsung atau melalui media perantara (diperoleh dan dicatat oleh pihak lain) yang umumnya berupa bukti, catatan, atau laporan historis yang telah tersusun arsip yang dipublikasikan dan yang tidak dipublikasi (Sadikin, 2011). data ini diambil dari laporang keuangan di www.idx.co.id. 


\section{Populasi dan Sampel}

Populasi dalam peneliti ini adalah perusahaan sektor perbankan yang terdaftar di Bursa Efek Indonesia (BEI) selama lima tahun terakhir yaitu dari tahun 2008 sampai 2012.

Dalam penentuan sampel menggunakan purposive sampling dengan kriteria pemilihan sampel adalah:

1. Telah terdaftar di BEI sebelum tahun 2008 dan tetap terdaftar di BEI selama periode pengamatan sampel (2008-2012)

2. Menerbitkan laporan keuangan secara rutin selama periode pengamatan sampel maupun sebelum periode pengamatan sampel (2008-2012)

3. Mempunyai data lengkap atau tersedianya informasi mengenai komponenkomponen yang digunakan untuk menghitung rasio keuangan bank yaitu variabel LDR, NPL, ROA, ROE, BOPO, NIM dan PDNselama periode pengamatan

4. Total aset selama lima tahun minimal 100 Triliun

Berdasarkan kriteria penetapan sample diatasdiperoleh empat sampel dari bank pemerintah dan empat sampel dari bank swasta yang memenuhi kriteria sebagai berikut:

Tabel 1

Total aset masing-masing sampel bank pemerintah di BEI (Dalam jutaan rupiah)

\begin{tabular}{|l|l|l|l|l|l|l|}
\hline No & Bank & 2008 & 2009 & 2010 & 2011 & 2012 \\
\hline 1 & BNI & 200.390 .507 & 225.541 .328 & 240.590 .147 & 288.511 .901 & 321.534 .240 \\
\hline 2 & BRI & 246.026 .225 & 314.745 .744 & 398.393 .138 & 456.531 .093 & 535.209 .156 \\
\hline 3 & BTN & 44.992 .171 & 58.516 .058 & 68.358 .539 & 89.121 .459 & 111.748 .593 \\
\hline 4 & MANDIRI & 338.404 .265 & 370.310 .994 & 407.826 .161 & 489.106 .664 & 563.105 .056 \\
\hline
\end{tabular}

Tabel 2

Total aset masing-masing sampel bank swasta di BEI (Dalam jutaan rupiah)

\begin{tabular}{|l|l|l|l|l|l|l|}
\hline No & Bank & 2008 & 2009 & 2010 & 2011 & 2012 \\
\hline 1 & BCA & 244.729 .257 & 280.814 .308 & 321.973 .412 & 377.250 .966 & 436.795 .410 \\
\hline 2 & BII & 53.790 .683 & 58.701 .483 & 71.624 .563 & 90.740 .977 & 111.161 .003 \\
\hline 3 & $\begin{array}{l}\text { CIMB } \\
\text { NIAGA }\end{array}$ & 102.604 .732 & 106.803 .360 & 142.637 .071 & 164.137 .582 & 192.612 .817 \\
\hline 4 & $\begin{array}{l}\text { BANK } \\
\text { PANIN }\end{array}$ & 62.772 .547 & 76.075 .202 & 105.424 .496 & 118.261 .916 & 141.450 .516 \\
\hline
\end{tabular}

Sumber : hasil penelitian 2013

\section{Metode Analisis}

Metode analisis yang digunakan dalam penelitian ini adalah sebagai berikut:

1. Perhitungan Rasio Keuangan

Analisis ini dilakukan untuk menghitung rasio-rasio keuangan pada sampel bank-bank yang terpilih sesuai dengan kriteria-kriteria yang telah ditetapkan di atas.

2. Pengujian Hipotesis

Analisis ini dilakukan untuk mengetahui apakah ada perbedaan yang signifikan dari kondisi LDR, NPL, ROA, ROE, BOPO, NIM dan PDN pada bank pemerintah dibandingkan dengan bank swasta yang menggunakan beberapa 
langkah analisis data, yaitu :

Uji Beda

Untuk menguji hipotesis, maka dilakukan uji beda dua mean (pair sample $t$ test). Jika probabilitas $>0,05$ maka $\mathrm{H} 0$ diterima, dan jika probabilitas $<0,05$ maka H0 di tolak. Sedangkan Null Hipotesis dan Hipotesis alternatif dapat di tetapkan sebagai berikut:

$\mathrm{H}_{0}: \mu 1=\mu 2$

Tidak terdapat perbedaan signifikan pada LDR, NPL,ROA, ROE, BOPO, NIM dan PDNyang terjadi pada kinerja keuangan bank pemerintah dan bank swasta.

$\mathrm{H}_{\mathrm{a}}: \mu 1 \neq \mu 2$

Terdapat perbedaan signifikan pada LDR, NPL, ROA, ROE, BOPO, NIM dan PDNyang terjadi pada kinerja keuangan bank pemerintah dan bank swasta.

Kriteria pengambilan keputusan dilakukan dengan membandingkan nilai $t$ Statistik (hitung) dengan nilai $\mathrm{t}$ kritis (tabel). Dimana taraf signifikan yang diterapkan dalam analisis ini adalah dengan $\alpha 5 \%$.

Jika $\mathrm{t}_{\text {hitung }}<\mathrm{t}_{\text {tabel }}$, maka $\mathrm{H}_{0}$ diterima dan $\mathrm{H}_{1}$ ditolak

Jika $\mathrm{t}_{\text {hitung }}>\mathrm{t}_{\text {tabel, }}$, maka $\mathrm{H}_{0}$ ditolak dan $\mathrm{H}_{1}$ diterima

Jika signifikansi $\mathrm{t}>0,05$, maka $\mathrm{H}_{0}$ diterima $\mathrm{H}_{1}$ ditolak

Jika signifikansi $\mathrm{t}<0,05$, maka $\mathrm{H}_{0}$ ditolak $\mathrm{H}_{1}$ diterima.

\section{HASIL DAN PEMBAHASAN}

Rata-rata Kinerja Keuangan Bank Pemerintah dan Bank Swasta Periode 20082012 dengan Menggunakan Rasio-Rasio Keuangan

1. Kinerja Keuangan Berdasarkan Loanto Deposit Ratio (LDR)

Rata-rata kinerja keuangan bank menggunakan rasio Loan to Deposit Ratio (LDR) padabank pemerintah dan bank swasta selama lima tahun dari 20082012. Untuk bank pemerintah memiliki LDR sebesar79,427 \% sedangkan bank swasta memiliki LDR sebesar 77,8515 \%. Tampak bahwa kinerja bank pada bank pemerintah lebih baik dibandingkan pada bank swasta.

2. Kinerja Keuangan Berdasarkan Non Performing Loan (NPL)

Rata - rata kinerja keuangan menggunakan rasio Non Performing Loan (NPL) pada bank pemerintah dan bank swasta selama lima tahun dari 2008-2012. Untuk bank pemerintah memiliki NPL sebesar1,2225 \% sedangkan pada bank swasta sebesar 1,1215 \%. Tampak bahwa kinerja bank pada bank swasta lebih baik dibandingkan pada bank pemerintah.

3. Kinerja keuangan berdasarkan rasio Return on Assets (ROA)

Rata - rata kinerja keuangan menggunakan rasio Return on Assets (ROA) pada bank pemerintah dan bank swasta selama lima tahun dari 2008-2012. untuk bank pemerintah memiliki ROA sebesar 2,974 \% sedangkan pada bank swasta sebesar 2,1865 \%. Tampak bahwa kinerja bank pada bank pemerintah lebih baik dibandingkan pada bank swasta.

4. Kinerja keuangan berdasarkan rasio Return on Equity (ROE)

Rata-rata kinerja keuangan bank pemerintah sebesar 25,7885\% lebih besar dari pada bank swasta sebesar 17,91\%. hal ini berarti kemampuan kin e rja 
keuangan dalam manajemen bank pemerintah untuk mengelola modal yang ada untuk memperoleh laba bersih dari kegiatan operasional sangat baik.

5. Kinerja keuangan berdasarkan rasio Biaya Operasional terhadap Pendapatan Operasional(BOPO)

Rata-rata rasio Biaya Operasional terhadap Pendapatan Operasional (BOPO)bank swasta lebih tinggi yaitu sebesar 79,924 \% dibandingkan dengan bank pemerintah sebesar 75,1215 \%. Hal ini menunjukkan bahwa bank swasta memiliki kemampuan tidak baik dalam mengelola biaya operasional untuk menghasilkan pendapatan dibandingkan bank pemerintah.

6. Kinerja keuangan berdasarkan rasio Net Interest Margin (NIM)

Rata-rata Net Interest Margin (NIM) pada bank pemerintah dan bank swasta selama lima tahun dari tahun 2008-2012. Dapa tdilihat bahwa bank pemerintah sebesar 6,5985 \% sedangkan bank swasta hanya sebesar5,4555 \%. Tampak bahwa kinerja bank pemerintah lebih baik dibandingkan pada bank swasta. Hal ini terjadi karena semakin besar rasio Net Interest Margin ( NIM) suatu bank, maka semakin besar pula pendapatan bunga yang diterima oleh bankt ersebut.

7. Kinerja keuangan berdasarkan rasio Posisi Devisa Netto ( P D N)

Rata-rata kinerja keuangan pada rasio Posisi Devisa Netto ( PDN) yang dimiliki oleh bank pemerintah lebih tinggi yaitu sebesar 3,6075 \% dibandingkan dengan Bank Swasta yang hanya2,983 \%. Ini berarti bank pemerintah memiliki risiko yang lebih besar dalam memenuhi kewajiban penyediaan modal minimum dengan memperhitungkan risiko pasar dibandingkan BankSwasta.

Uji beda Kinerja Keuangan Bank Pemerintah Dan Bank Swasta Periode 20082012 Menggunakan Analisis Beda Dua Mean (Pair Sample T Test)

1. Uji beda kinerja keuangan berdasarkan Loan to Deposit Ratio(LDR)

Diketahui nilai sig (2-tailed) yaitu 0,571 >0,05 maka $\mathrm{H}_{0}$ diterima artinya tidak ada perbedaan kinerja keuangan antara bank pemerintah dengan bank swasta dari rasio keuangan Loanto Deposit Ratio(LDR). Sementara, dilihat dari nilai t hitung $=0,577<$ nilai $t_{\text {tabel }}=2,093$ maka Ho diterima artinya tidak ada perbedaan kinerja keuangan antara bank pemerintah dengan bank swasta dari rasio keuangan Loan to Deposit Ratio(LDR).

2. Uji beda Kinerja Keuangan Berdasarkan Non Performing Loan (NPL)

Diketahui nilai sig (2-tailed) yaitu 0,693 >0,05 maka $\mathrm{H}_{0}$ diterima artinya tidak ada perbedaan kinerja keuangan antara bank pemerintah dengan bank swasta dari rasio keuangan Non Performing Loan (NPL).Sementara, dilihat dari nilai t hitung $=0,401<\mathrm{t}$ tabel $=2,093$ maka Ho diterima artinya tidak ada perbedaan kinerja keuangan antara bank pemerintah dengan bank swasta dari rasio keuangan Non Performing Loan (NPL).

3. Uji Beda Kinerja Keuangan Berdasarkan Return on Assets (ROA)

Diketahui nilai sig (2-tailed) yaitu 0,093>0,05 maka $\mathrm{H}_{0}$ diterima artinya tidak ada perbedaan kinerja keuangan antara bank pemerintah dengan bank swasta dari rasio keuangan Return on Assets (ROA).Sementara, dilihat dari nilai $\mathrm{t}_{\text {hitung }}=$ $1,766<\mathrm{t}$ tabel $=2,093$ maka Ho diterima artinya tidak ada perbedaan kinerja keuangan antara bank pemerintah dengan bank swasta dari rasio keuangan Return on Assets (ROA)

4. Uji Beda Kinerja Keuangan Berdasarkan Return On Equity (ROE) 
Diketahui nilai sig (2-tailed) yaitu 0,066 $>0,05$ maka $\mathrm{H}_{0}$ diterima artinya tidak ada perbedaan kinerja keuangan antara bank pemerintah dengan bank swasta dari rasio keuangan Return On Equity (ROE). Sementara, dilihat dari nilai $\mathrm{t}_{\text {hitung }}=1,952<\mathrm{t}$ tabel $=2,093$ maka Ho diterima artinya tidak ada perbedaan kinerja keuangan antara bank pemerintah dengan bank swasta dari rasio keuangan Return On Equity (ROE).

5. Uji Beda Kinerja Keuangan Berdasarkan Kinerja keuangan berdasarkan rasio Biaya Operasional terhadap Pendapatan Operasional (BOPO)

Diketahui nilai sig (2-tailed) yaitu 0,194 lebih $>0,05$ maka $\mathrm{H}_{0}$ diterima artinya tidak ada perbedaan antara kinerja keuangan bank pemerintah dengan bank swasta dilihat dari rasio keuangan Biaya Operasional terhadap Pendapatan Operasional (BOPO). Sementara, dilihat dari nilai $\mathrm{t}_{\text {hitung }}=-1,347<\mathrm{t}_{\text {tabel }}=2,093$ maka Ho diterima artinya tidak ada perbedaan kinerja keuangan antara bank pemerintah dengan bank swasta dari rasio keuangan Biaya Operasional terhadap Pendapatan Operasional (BOPO).

6. Uji Beda Kinerja Keuangan Berdasarkan Net Interest Margin (NIM)

Diketahui nilai sig (2-tailed) yaitu $0,017<0,05$ maka $\mathrm{H}_{0}$ ditolak artinya ada perbedaan antara kinerja keuangan bank pemerintah dengan bank swasta dilihat dari rasio keuangan Net Interest Margin (NIM). Sementara, dilihat dari nilai $\mathrm{t}_{\text {hitung }}=2,607>\mathrm{t}$ tabel $=2,093$ maka Ho ditolak artinya ada perbedaan kinerja keuangan antara bank pemerintah dengan bank swasta dari rasio Net Interest Margin (NIM).

7. Uji BedaKinerja Keuangan Berdasarkan Posisi Devisa Netto (P D N)

Diketahui nilai sig (2-tailed) yaitu 0,528 >0,05 maka $\mathrm{H}_{0}$ diterima. Sementara, dilihat dari nilai $\mathrm{t}$ hitung $=0,643<\mathrm{t}$ tabel $=2,093$ maka Ho diterima. Dapat disimpulkan bahwa tidak terdapat perbedaan yang signifikan antara bank pemerintah dengan bank swasta ditinjau dari rasio keuangan Posisi Devisa Netto ( P D N).

\section{Pembahasan}

Berdasarkan hasil penelitian menunjukan bahwa dapat diketahui nilai sig (2-tailed) yaitu 0,571 lebih besar dari nilai taraf pengujian sebesar 0,05 maka $\mathrm{H}_{0}$ diterima artinya tidak ada perbedaan kinerja keuangan antara bank pemerintah dengan bank swasta dari rasio keuangan Loanto Deposit Ratio (LDR). Rasio ini menggambarkan kemampuan bank membayar kembali penarikan yang dilakukan deposan dengan mengendalikan kredit yang diberikans ebagai sumber likuiditasnya. Semakin tinggi rasio tersebut memberi indikasi semakin tingginya kemampuan likuiditas suatu bank tersebut.

Dilihat dari indikator Non Performing Loan (NPL), diketahui nilai sig (2-tailed) yaitu 0,693 lebih besar dari nilai taraf pengujian sebesar 0,05 maka $\mathrm{H}_{0}$ diterima artinya tidak ada perbedaan kinerja keuangan antara bank pemerintah dengan bank swasta dari rasio keuangan Non Performing Loan (NPL). Rasio ini menunjukkan semakin tinggi nilai Non Performing Loan (NPL), semakin buruk kualitas kredit yang bersangkutan karena jumlah kredit bermasalah semakin besar dan jika rasio Non Performing Loan (NPL) rendah akan menghasilkan pendapatan bertambah dan meningkatkan laba perusahaan tersebut.

Dari indikator Return On Asset (ROA), diketahui nilai sig (2-tailed) yaitu 0,093 lebih besar dari nilai taraf pengujian sebesar 0,05 maka $\mathrm{H}_{0}$ diterima artinya tidak 
ada perbedaan kinerja keuangan antara bank pemerintah dengan bank swasta dari rasio keuangan Return on Assets (ROA). Rasio ini Menjaga tingkat profitabilitas merupakan hal yang penting bagi bank karena profitabilitas yang tinggi merupakan tujuan setiap bank. Jika dilihat dari perkembangan rasio profitabilitas menunjukkan suatu peningkatan hal tersebut menunjukkan kinerja bank efisien. Semakin tinggi Return on Assets (ROA) semakin tinggi pula tingkat keuntungan yang dicapai perusahaan tersebut.

Dari Indikator Return On Equity (ROE), diketahui nilai sig (2-tailed) yaitu 0,066 lebih besar dari nilai taraf pengujian sebesar 0,05 maka $\mathrm{H}_{0}$ diterima artinya tidak ada perbedaan kinerja keuangan antara bank pemerintah dengan bank swasta dari rasio keuangan Return On Equity (ROE). Rasio ini menunjukan perbandingan antara laba bersih bank dengan modal sendiri. Rasio ini digunakan untuk mengukur kemampuan manajemen bank dalam mengelola modal yang ada untuk memperoleh laba bersih dari kegiatan operasional. Semakin tinggi Return On Equity (ROE) semakin baik dalam menggelolah modal yang ada untuk memperoleh laba bersih dari kegiatan oprasional.

Dari indikator Beban Operasional \& Pendapatan Operasional (BOPO), diketahui nilai sig (2-tailed) yaitu 0,194 lebih besar dari nilai taraf pengujian sebesar 0,05 maka $\mathrm{H}_{0}$ diterima artinya tidak ada perbedaan antara kinerja keuangan bank pemerintah dengan bank swasta dilihat dari rasio keuangan Biaya Operasional terhadap Pendapatan Operasional (BOPO). Rasio ini digunakan untuk mengukur tingkat efisiensi dan kemampuan bank dalam melakukan kegiatan operasionalnya. Semakin rendah rasio ini, semakin baik kemampuan perusahaan mengolah biaya oprasional untuk menghasilkan pendapatan perudsahaan.

Dari indikator Net Interest Margin (NIM), diketahui nilai sig (2-tailed) yaitu 0,017 lebih kecil dari nilai taraf pengujian sebesar 0,05 maka $\mathrm{H}_{0}$ ditolak artinya ada perbedaan antara kinerja keuangan bank pemerintah dengan bank swasta dilihat dari rasio keuangan Net Interest Margin (NIM). Rasio ini digunakan untuk mengukur kemampuan manajemen bank dalam mengelola aktiva produktifnya untuk menghasilkan pendapatan bunga dari kegiatan operasional bank. Semakin tinggi Nett Interest Margin (NIM), semakin tinggi pula pendapatan bunga yang diterima oleh perusahaan tersebut.

Dan yang terakhir dari indikator Posisi Devisa Netto (PDN), diketahui nilai sig (2-tailed) yaitu 0,528 lebih besar dari nilai taraf pengujian sebesar 0,05 maka $\mathrm{H}_{0}$ diterima artinya tidak ada perbedaan antara kinerja keuangan bank pemerintah dengan bank swasta dilihat dari rasio keuangan Posisi Devisa Netto ( P D N). Rasio ini digunakan agar bank selalu menjaga keseimbangan posisi antara sumber dana valas dan penggunaan danavalas. Semakin rendah PosisiDevisaNetto (PDN), maka semakin baik pula resiko dalan memenuhi kewajiban penyediaan modal minimum dengan memperhitungkan resiko pasar

Dari ketujuh rasio keuangan yang diteliti hanya satu rasio keuangan yang terdapat perbedaan signifikan artinya ada perbedaan kinerja keuangan antara bank pemerintah dengan bank swasta yaitu dari rasio keuangan Net Interest Margin (NIM). Hasil pembuktian hipotesis ini diperkuat dengan hasil penelitian yang dilakukan oleh Ahmad MuizzulAlim (2010) yang menunjukan bahwa Terdapat perbedaan yang signifikan pada rasio Net Interest Margin (NIM) diantara bankbank umum swasta nasional yang gopublic. Dengan demikian hipotesis keenam 
penelitian ini yang menduga bahwa terdapat perbedaan yang signifikan pada Net Interest Margin (NIM) di antara keempat bank pada sampel penelitian diterima.

\section{KESIMPULAN DAN SARAN}

\section{Kesimpulan}

Berdasarkan hasil analisis data dan pembahasan, dapat ditarik kesimpulannya yaitu

1. Tidak terdapat perbedaan yang signifikan antara bank pemerintah dan bank swasta ditinjau dari rasio keuangan LDR, NPL, ROA, ROE, BOPO dan P D N .

2. Terdapat perbedaan yang signifikan antara bank pemerintah dengan bank swasta ditinjau dari rasio keuangan NIM.

\section{Saran}

Adapun saran yang dapat diberikan dalam penelitian ini adalah :

1. Bagi pihak investor sebelum memutuskan untuk berinvestasi terhadap suatu bank, hendaknya mempertimbangkan faktor-faktor kesehatan dan kinerja keuangannya terlebih dahulu, seperti: LDR, NPL, ROA, ROE, BOPO, NIM, PDN.

2. Bagi perusahaan hendaknya dalam menghitung laporan keuangan menggunakan rasio-rasio keuangan dengan lengkap supaya kinerja keuangan suatu perusahaan tersebut dinilai lebih baik dan mengunakan laporan yang benar.

3. Untuk penelitian selanjutnya diharapkan agar menggunakan subjek penelitian, periode penelitian dan menggunakan variabel yang berbeda, sehingga dapat menambah wawasan dalam penelitian kinerja keuangan bank serta diharapkan dapat memperoleh hasil yang lebih baik dari penelitian-penelitian sebelumnya, agar dapat dijadikan acuan yang lebih baik untuk peneliti seterusnya.

\section{DAFTAR PUSTAKA}

Afriansyah. 2006. "Membandingkan Kinerja Bank BUMN dan Bank Swasta Periode 2005-2006". Skripsi. Universitas Bengkulu.

Bank Indonesia, Surat Edaran No 6/23/PPNP Tanggal 31 Mei 2004, Perihal Tata Cara Penilaian Kesehatan Bank, www.bi.go.id.

Bank Indonesia. 2004. Peraturan Bank Indonesia Nomor 6/10/PBI/2004 tanggal 12 April2004 perihal Sistem Penilaian Tingkat Kesehatan Bank Umum. JakartaBank Indonesia.

Dendawijaya. 2006. Manajemen Perbankan. Ghalia Indonesia. Jakarta.

Departemen Keuangan Republik Indonesia. 1998. Undang-Undang Republik Indonesia No. 10 Tahun 1998 tentang Perubahan atas Undang-Undang Nomor 7 tahun 1992Tentang Perbankan. Jakarta Departemen Keuangan Republik Indonesia.

Febriyani dan Zukpadin. 2003. "Perbandingan Kinerja pada Industry Perbankan antara Bank Devisa dan Bank Non Devisa Periode Krisis Ekonomi”. Skripsi. Universitas Bengkulu.

Henry. 2007. "Membandingkan Kinerja Bank BUMN dan Bank Asing Periode 2005- 
2006”. Skripsi. Universitas Bengkulu.

Http:\\www.bi.go.id

Imam Ghozali. 2006. Aplikasi analisis multivariatedenganprogram SPSS. Semarang : Badan Penerbit Universitas Dipenogoro.

Indira Januarti,(2002), “ Variabel Proksi CAMEL dan Karakteristik Bank Lainnya Untuk Memprediksi Kebangkrutan Bank di Indonesia”.Jurnal Bisnis Strategi,Vol.10,Desember,hal.1-26.

Kasmir. 2002. Bank dan Permodalan. Rineka Cipta. Jakarta.

Lukman Denda wijaya.2003. Manajemen Perbankan. Ghalia Indonesia : Jakarta.

Martono, Cyrillius, (2002),"Analisis Pengaruh Profitabilitas industri, rasio Leverage Keuangan Tertimbang dan Intensitas Modal Tertimbang Serta Pangsa Pasar Terhadap ROA dan ROE Perusahaan ManufakturYangGoP ublik di Indonesia," Jurnal Akuntansi dan Keuangan, Vol,4,No.2,November,2002,pp.126-140

Meythi, (2005), "Rasio Keuangan yang paling baik untuk memprediksi PertumbuhanLaba: Suatu studi empiris pada Perusahaan Manufaktur yang terdaftar di Bursa Efek Jakarta, "Jurnal Ekonomi dan Bisnis,Vol XI, No.2, September, 2005

Mudrajad kuncoro, Suharjono. 2002. Manajemen perbankan : Teori dan Aplikasi untuk Bisnis dan Ekonomi. Edisi kedua. Penerbit BPFE. Yogyakarta.

Nasser, Etty M dan Titik Aryati, 2000, "Model Analisis CAMEL Untuk Memprediksi Financial Distress Pada Sektor Perbankan Yang Go Publik,"JAAI,Vol,4,No.2

Pratiwi, ami. 2008. "Analisis Kinerja Keuangan PT.Bank Tabungan Negara (persero) Indonesia periode tahun 2004-2006 berdasarkan standar yang ditetapkan Bank Indonesia". Skripsi. Universitas Bengkulu.

Sadikin, A. 2011. Analisis Abnormal Return Saham dan Volume Perdagangan Saham, Sebelum Peristiwa Pemecahan Saham. Jurnal manajemen dan Akuntansi. Volume 12 Nomor 01.

Sahuliyah, Muhtar. 2010. "Analisis Pengaruh Kinerja Keuangan Perbankan Terhadap Harga Saham”. Skripsi. Universitas Bengkulu.

Sunariyah. 2004. Pengantar Pengetahuan Pasar Modal. Akademi ManajemenPerusahaanYKPNYogyakarta

Sutaryono. 2007. Kinerja Bank Umum Swasta Indonesia. Jurnal Ekonomi Fakultas Ekonomi Tarumanegara. Vol. III No. 02.

Sutami. 2011. "Perbedaan Kinerja Keuangan Bank Pemerintah Dan Bank Swasta Pada Bank Yang Go Public Di Bursa Efek Indonesia". Skripsi . Universitas Bengkulu.

Tanggulangan, gustin. 2007. "Komparasi Kinerja Keuangan Bank Pemerintah dan Bank Swasta". Skripsi. Universitas Kristen Satya Wacana.

Totok Budisantoso dan Sigit Triandaru, 2006 Bank dan Lembaga keuangan lainya.Penerbit Salemba Empat. 